\title{
Pelatihan Model Pembelajaran Menggunakan Microsoft Teams di SD Muhammadiyah 2 Denpasar
}

\author{
Evi Triandini ${ }^{1}$, Indrianto ${ }^{2}$, Ratna Kartika W ${ }^{3}$ \\ evi@stikom-bali.ac.id'1 , indrianto@stikom-bali.ac.id², Ratna@stikom-bali.ac.id ${ }^{3}$ \\ 1,2,3 Institut Teknologi dan Bisnis STIKOM Bali
}

\begin{tabular}{l}
\hline Article History: \\
Received: $19-09-2021$ \\
Revised: 23-11-2021 \\
Accepted: 10-01-2022
\end{tabular}

Keywords: Online learning media, Whatsapp, Zoom, Microsoft Teams

\begin{abstract}
SD Muhammadiyah 2 Denpasar is a partner of this service activity. The number of teachers who teach at this school is 42 people. SD Muhammadiyah 2 Denpasar seeks to provide services in an innovative, creative and fun learning process, based on the student center method to increase and develop the potential of students. During the Covid-19 Pandemic, schools held online learning. The learning process is done by giving assignments and asking students to learn the material in the book through Whatsapp media. Then, The teacher and the students discuss the material given via whatsapp. The school also uses free zoom app. With limited time and the number of participants. So that, bone learning topic can not be finished in one section of learning process. Likewise, the limitation of 100 participants also creates obstacles in the learning process because there are subjects that are attended by more than 100 students. To overcome these problems, Microsoft Teams will be used as a learning media in this school. The first phase of activity, namely providing training on Microsoft Teams learning media, has been carried out for two days by the proposing team. The training was attended by homeroom teachers for grades 4, 5 and 6. The training participants were very enthusiastic about participating in the training activities. Participants are able to practice directly the training material provided. The second phase of service activities was continued by evaluating and monitoring the use of MsTeams by participants who had received training in previous service activities. The results of the evaluation showed that this training activity gave satisfaction to the participants because the training topics provided provided an alternative to the use of digital media for learning for students at SD Muhammadiyah 2 Denpasar.
\end{abstract}

\section{Pendahuluan}

SD Muhammadiyah 2 Denpasar, Bali, merupakan mitra kegiatan pengabdian ini. SD Muhammadiyah 2 Denpasar sebagai amal usaha di bawah naungan Majelis Pendidikan Dasar dan Menengah PDM Kota Denpasar, berkomitmen untuk meningkatkan mutu dan kualitas pendidikan dengan mengimplementasikan kurikulum 2013, kurikulum Muhammadiyah, dan Muatan Lokal dengan menguatkan karakter pendidikan Islami. Untuk mewujudkan tujuan tersebut, diperlukan tekad yang kuat dan tindakan yang konsisten dari seluruh stakeholders di lingkungan SD Muhammadiyah 2 Denpasar dengan dukungan 
Komite Sekolah, Majelis Dikdasmen PDM Kota Denpasar, dan Dinas Pendidikan dan Kebudayaan Kota Denpasar.

Jumlah guru yang mengajar di SD Muhammadiyah 2 Denpasar sebanyak 42 orang (ditunjukan pada Gambar 1). Fasilitas yang telah dimiliki oleh sekolah tersebut antara lain ICT Learning Media, Computer Laboratory, Science Laboratory, Language Laboratory, ELearning Laboratory, Hotspot/Internet serta fasilitas lainnya (Fasilitas yang dimiliki SD Muhammadiyah 2 Denpasar dapat dilihat pada Gambar 2).

SD Muhammadiyah 2 Denpasar berupaya memberikan pelayanan dalam proses pembelajaran yang inovatif, kreatif dan menyenangkan, serta mengacu pada student center, yang diharapkan dapat meningkatkan dan mengembangkan potensi yang dimiliki oleh peserta didik. Masa Pandemi Covid-19, sekolah mengadakan pembelajaran secara daring. Media pembelajaran yang digunakan untuk mendukung proses pembelajaran pada awal masa pandemi yaitu Whatsapp. Whatsapp digunakan oleh guru untuk memberikan tugas dan materi pembelajaran di buku paket yang harus dipelajari oleh siswa. Diskusi materi pembelajaran juga dilakukan melalui Whatsapp.

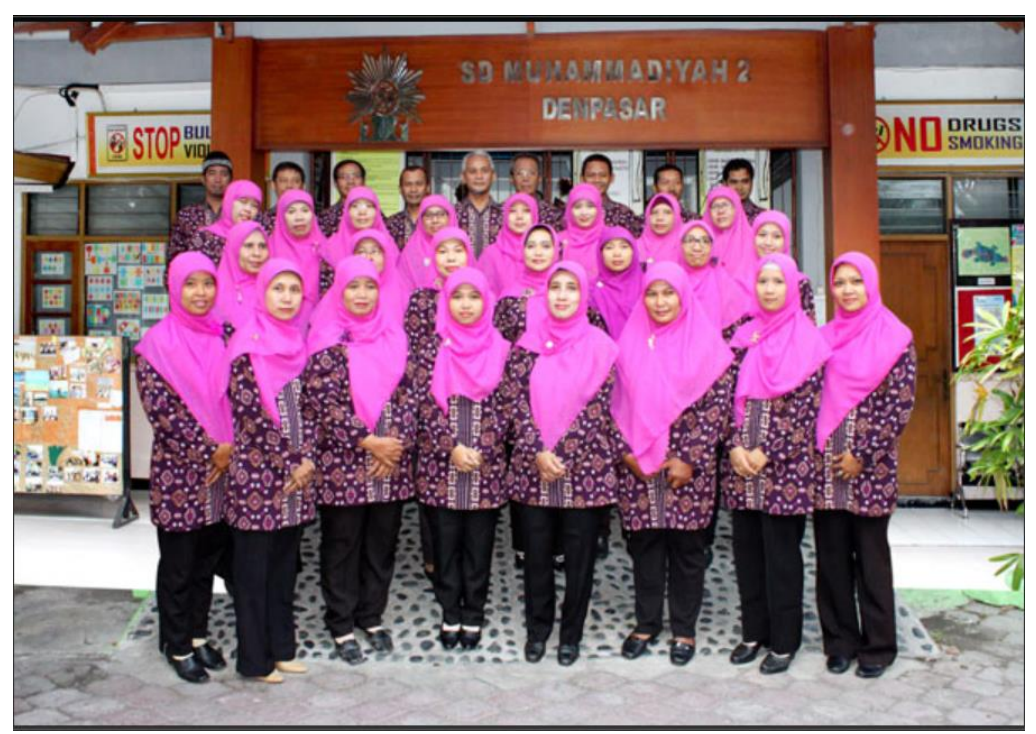

Gambar 1. Guru SD Muhammadiyah 2 Denpasar 


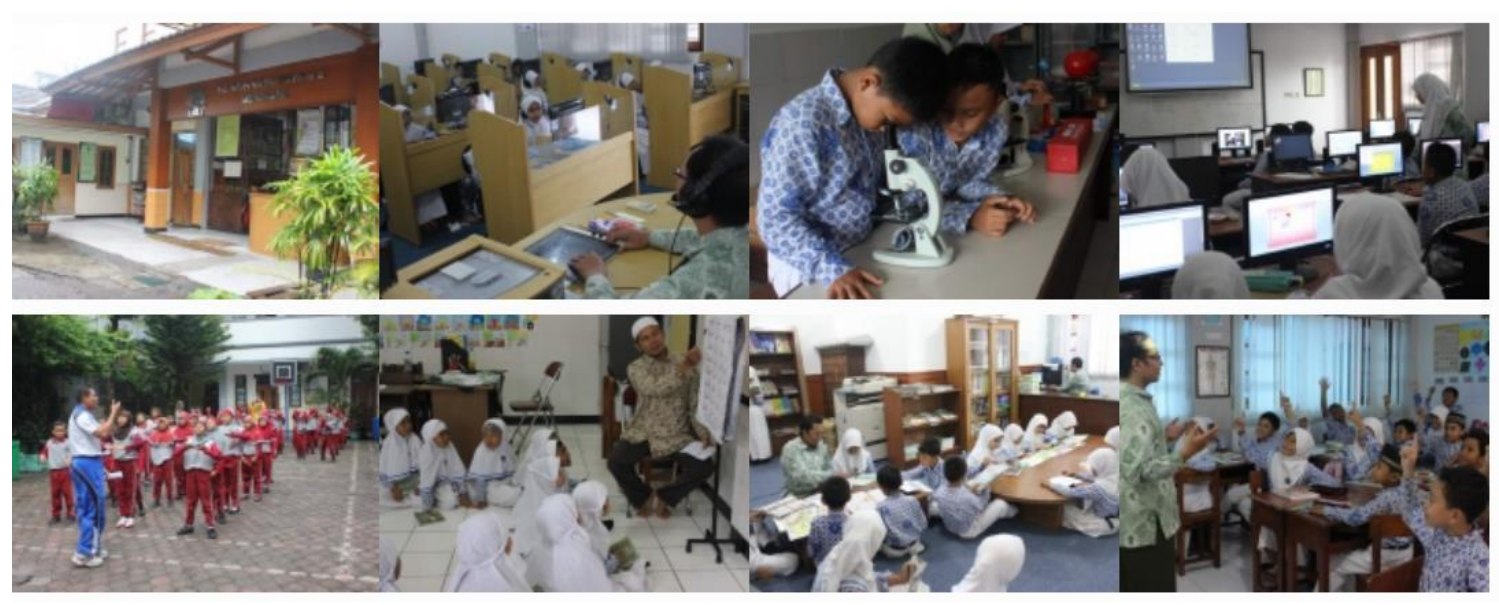

Gambar 2. Fasilitas SD Muhammadiyah 2 Denpasar

Zoom meeting secara bertahap digunakan oleh sekolah untuk mendukung pembelajaran yang lebih interaktif dan komunikatif. Menurut Hakein Haqien \& Rahman (2020) zoom meeting merupakan salah satu media pembelajaran yang menyediakan komunikasi individu secara lisan dibandingkan dengan media pembelajaran yang tertulis. Namun, sekolah ini masih menggunakan aplikasi zoom yang tidak berbayar. Hal ini menimbulkan permasalahan karena adanya batasan waktu pemakaian zoom yakni hanya selama 40 menit dan jumlah peserta dibatasi sebanyak 100 orang. Batasan waktu penggunaan zoom mengakibatkan proses pembelajaran yang tidak tuntas dalam satu topik pembelajaran. Demikian juga adanya batasan 100 orang peserta juga menimbulkan adanya kendala dalam proses pembelajaran karena ada matapelajaran yang diikuti oleh lebih dari 100 orang siswa.

Media pembelajaran daring lain sebagai alternatif untuk mengatasi permasalahan tersebut perlu disiapkan. Microsoft Teams merupakan media pembelajaran daring yang bisa digunakan oleh sekolah. Microsoft Teams adalah produk layanan berlangganan yang ditawarkan oleh Microsoft sebagai bagian dari lini produk Microsoft Office. Secara umum, fasilitas Microsoft 365 terdiri dari perangkat lunak Microsoft Office serta perangkat lunak berbasis komputasi awan sebagai produk layanan untuk lingkungan bisnis, seperti Hosting Exchange Server, Skype for Business Server, dan SharePoint ditambah opsi tambahan layanan Windows 10 Enterprise (Widiyarso \& Sutama, 2021).

Microsoft Teams adalah hub digital yang menyatukan percakapan, konten, penugasan, dan aplikasi di satu tempat, sehingga memungkinkan guru menciptakan lingkungan belajar yang dinamis. Microsoft bertujuan untuk menawarkan pengalaman belajar jarak jauh sebagai pribadi, menarik dan terhubung secara sosial seperti belajar di kelas. Microsoft Teams memungkinkan siswa dan guru dapat tetap berkomunikasi dan saling membantu menggunakan percakapan, dan dapat merasa seperti mereka bertemu langsung 
menggunakan pertemuan langsung. Guru dapat melacak kemajuan siswa dalam pekerjaan sehari-hari mereka menggunakan tugas, dan sama seperti di ruang kelas, guru dapat menggunakan aplikasi dan fungsi Tim untuk mendukung cara mereka bekerja terbaik (Amirullah, 2020; Ismanto \& Cindarbumi, 2021; Isti'anah, 2020; Pradja \& Baist, 2019; Situmorang, 2020; Widiyarso \& Sutama, 2021).

Berkenaan dengan uraian permasalahan yang dialami oleh mitra pengabdian, maka permasalahan yang telah diidentifikasi antara lain: a) pembelajaran secara daring yang telah dilakukan dengan menggunakan media pembelajaran zoom tanpa berbayar memiliki kendala karena keterbasan waktu pembelajaran dan jumlah peserta pembelajaran, b) guruguru belum memahami penggunaan Microsoft Teams sebagai media pembelajaran daring. Solusi yang diberikan sebagai kegiatan pengabdian yaitu mengadakan pelatihan media pembelajaran Microsoft Teams bagi guru-guru SD Muhammadiyah 2 Denpasar, Bali.

Target kegiatan pengabdian ini yaitu guru wali kelas 4, 5 dan 6 SD Muhammadiyah 2 Denpasar, Bali. Kegiatan ini hanya diperuntukan untuk jenjang kelas 4, 5 dan 6 pada jenjang kelas tersebut diasumsikan akan mudah beradaptasi untuk menggunakan media pembelajaran Microsoft Teams dalam proses belajar mengajar. Hasil kegiatan pengabdian ini yaitu adanya peningkatan pengetahuan dan kemampuan guru-guru untuk menggunakan Microsoft Teams sebagai media pembelajaran di sekolah. Fasilitas yang tersedia dalam Microsoft Teams yang dapat mendukung proses pembelajaran antara lain membuat grup kelas, menyediakan fasilitas untuk mengunggah materi pembelajaran, memberikan tugas dan evaluasi pengerjaan tugas, membuat penilaian hasil pembelajaran, dan melakukan proses pembelajaran secara interaktif dengan siswa

\section{Metode}

Metode kegiatan pengabdian yang digunakan yaitu pelatihan, praktek langsung dan pendampingan. Metode pelaksanaan kegiatan dilakukan secara bertahap seperti yang ditunjukan pada Gambar 3.

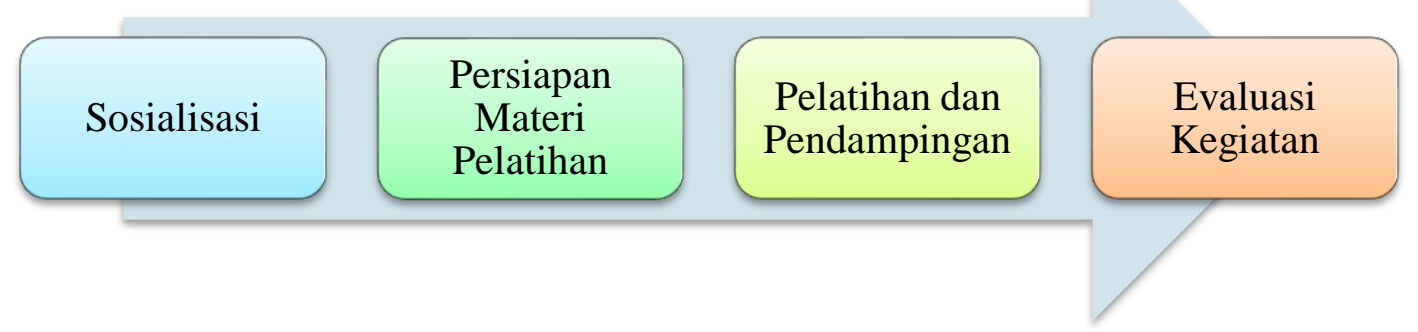

Gambar 3. Tahap pelaksanaan pengabdian

Uraian kegiatan yang dilaksanakan setiap tahap dijelaskan sebagai berikut: 
1. Sosialisasi Kegiatan

Sosialisasi kegiatan dilakukan secara daring dan luring. Tim pengabdian membuat grup Whatsapp dengan peserta pelatihan untuk mempermudah komunikasi dan koordinasi. Sosialisasi dilakukan untuk menyampaikan rencana pelaksanaan kegiatan pengabdian dan target luaran kegiatan yang akan dicapai dalam kegiatan pengabdian.

2. Persiapan Materi Pelatihan

Materi pelatihan yang akan diberikan ke mitra yaitu Micrososft Teams untuk pembelajaran dan Administrasi User Microsoft 365. Materi pelatihan dibuat oleh tim pengusul dalam bentuk modul pembelajaran. Detil materi yang akan diberikan dapat ditunjukan pada Tabel 1.

Tabel 1. Materi pelatihan

\begin{tabular}{l}
\hline \multicolumn{1}{c}{ Materi } \\
\hline Workshop MsTeams untuk pembelajaran di Sekolah \\
\hline a. Instalasi Msteam \\
b. Login ke Msteam \\
c. Mengelola Team \\
d. Menambah peserta kedalam Team \\
e. Melakukan Meeting \\
f. Menambah chanel \\
g. Membuat tugas \& Quiz \\
h. Membuat Form \\
\hline Administrasi User Ms Office 365 \\
\hline a. Microsoft Authenticator \\
b. Menambah User Basic \\
c. Menambah Multiple User \\
d. Setup Lisensi User
\end{tabular}

3. Pelatihan dan Pendampingan

Pelatihan dilakukan secara luring dengan mengikuti prosedur Kesehatan di masa Pandemi ini. Pelatihan dilakukan selama dua hari yaitu pada tanggal 21 Januari dan 5 Februari 2021. Kegiatan pelatihan dilakukan dengan praktek langsung oleh peserta. Kegiatan penyegaran materi dilakukan pada tanggal 31 Mei 2021. Tujuan kegiatan penyegaran yaitu untuk mendiskusikan materi yang telah dipelajari oleh mitra terkait dengan pemahaman dan kemampuan mitra untuk dapat menggunakan media pembelajaran Microsoft Teams. 


\section{Evaluasi Kegiatan}

Evaluasi kegiatan dilaksanakan secara daring menggunakan Google form. Komunikasi antara tim pengusul dan mitra dilakukan secara daring menggunakan Grup Whatsapp terkait dengan evaluasi kegiatan pengabdian yang telah dilaksanakan.

\section{Pembahasan}

Kegiatan pengabdian pada masyarakat pada semester ini atau pada tahap ini dilakukan dengan memberikan workshop penggunaan Microsoft Teams pada guru SD Muhammadiyah 2 Denpasar khususnya Guru kelas 4, 5 dan 6. Jumlah peserta yang mengikuti workshop sebanyak 6 orang. Kegiatan workshop dilaksanakan selama 2 hari yaitu pada tanggal 21 Januari 2021 dan tanggal 5 Februari 2021 ..

Kegiatan pelatihan pada hari pertama diawali dengan seremonial sederhana yang dihadiri oleh Kepala Sekolah SD Muhammadiyah 2 Denpasar. Kegiatan dilanjutkan dengan pemberian materi dan praktek langsung oleh guru-guru yang telah menyiapkan laptop masing-masing pada saat mengikuti pelatihan. Dokumentasi kegiatan hari pertama dapat dilihat pada Gambar 4 dan Gambar 5.

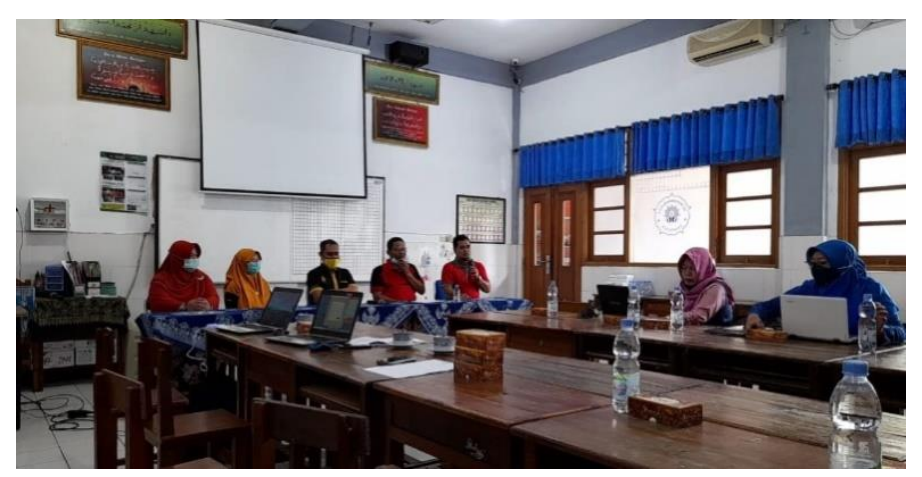

Gambar 4. Pembukaan pelatihan hari pertama

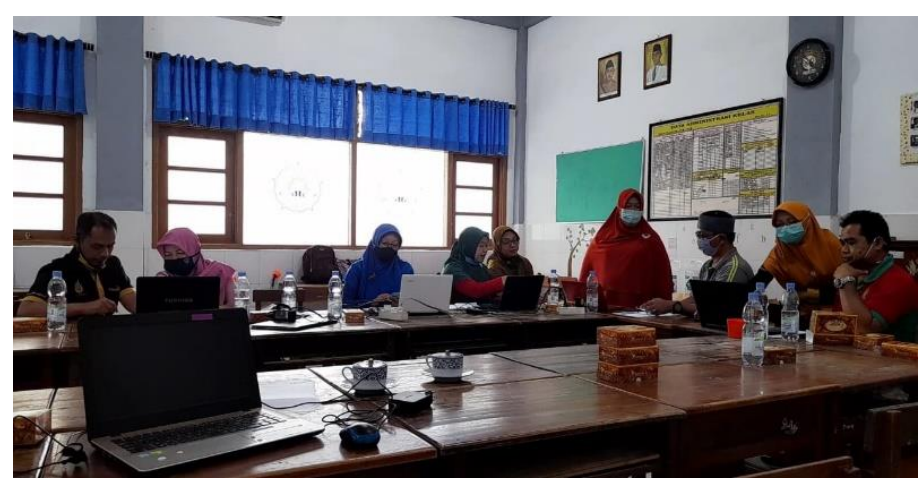

Gambar 5. Pelatihan hari pertama

Kegiatan hari kedua, tim pengusul langsung memberikan materi penggunaan Microsoft untuk level administrasi dan mempraktekan cara penggunaannya. Peserta https://journal.universitasbumigora.ac.id/index.php/ADMA 
pelatihan langsung mempraktekan materi tersebut menggunakan laptop masing-masing. Dokumentasi kegiatan hari kedua dapat dilihat pada Gambar 6.

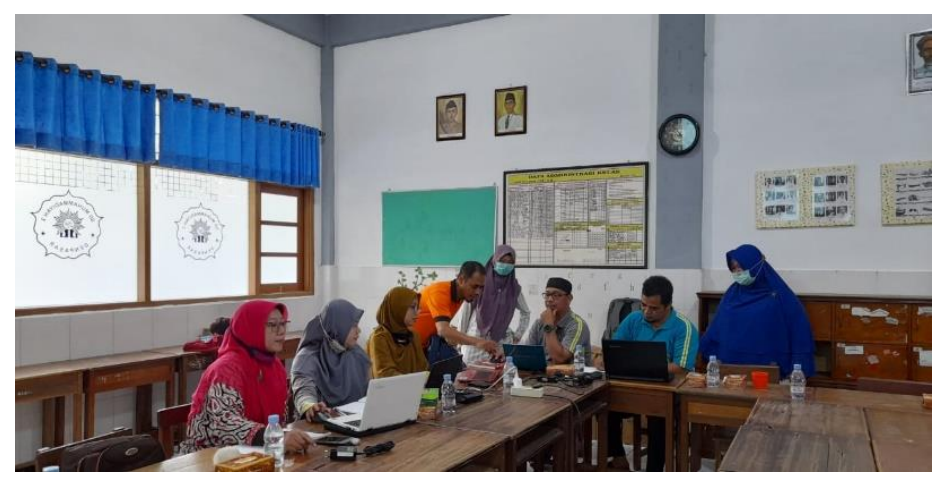

Gambar 6. Pelatihan hari kedua

Kegiatan penyegaran materi yang telah diberikan dilaksanakan pada tanggal $31 \mathrm{Mei}$ 2021. Rangkaian kegiatan yang dilaksanakan oleh tim pengabdian yaitu mengadakan diskusi dan mengulas dua materi pelatihan yang telah diberikan pada kegiatan sebelumnya. Berdasarkan hasil diskusi tersebut, peserta pelatihan telah memahami materimateri pelatihan yang telah diberikan oleh tim pengabdian. Kegiatan penyegaran ditunjukkan pada Gambar 7.

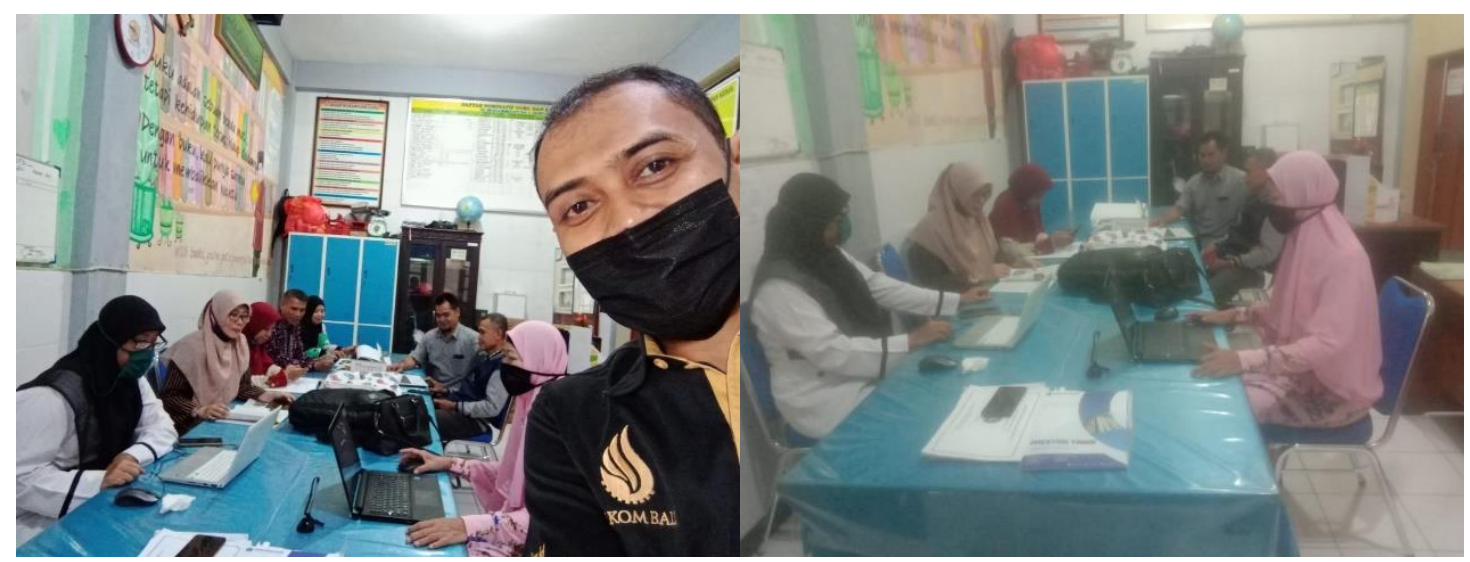

Gambar 7. Penyegaran

Evaluasi pelaksanaan kegiatan pengabdian telah dilakukan oleh tim pengabdian. Hasil Evaluasi kegiatan pengabdian menunjukkan bahwa peserta merasa puas dan nyaman dengan kegiatan pelaksanaan yang telah dilaksanakan oleh tim pengabdian. Hasil evaluasi kegiatan ditunjukkan pada Gambar 8. Keberlanjutan kegiatan pengabdian akan dilakukan oleh tim pengusul dengan melakukan komunikasi secara intensif pada sekolah untuk mengetahui manfaat kegiatan pengabdian yang telah dilakukan. 


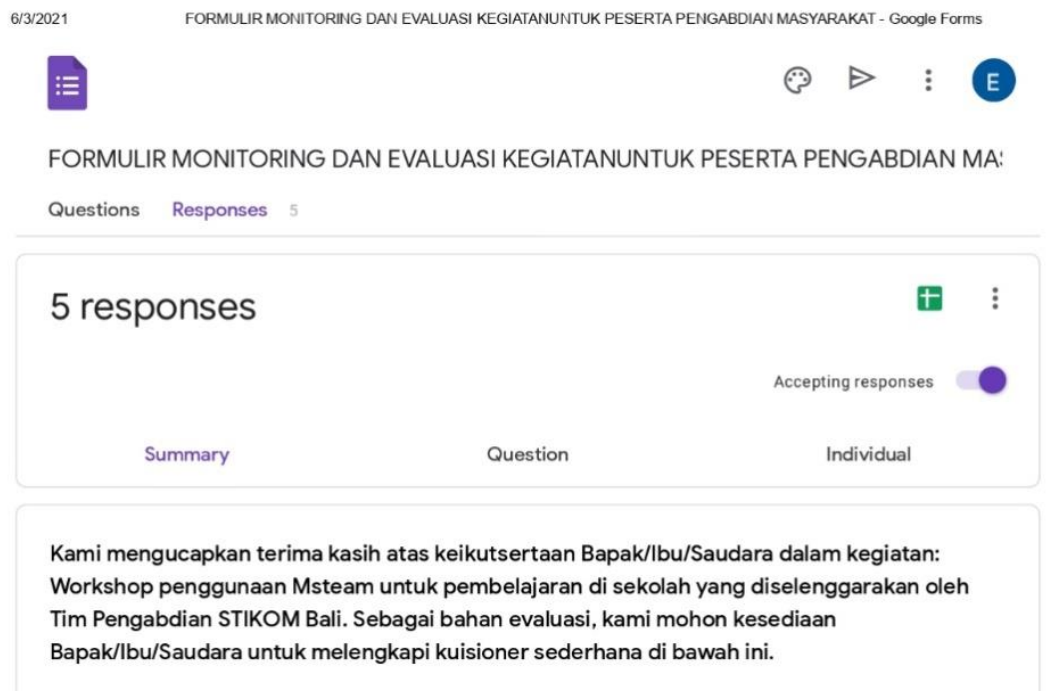

Gambar 8. Hasil evaluasi kegiatan

\section{Kesimpulan}

Kegiatan pelatihan penggunaan media pembelajaran Microsoft Teams telah diberikan ke mitra. Kegiatan penyegaran dan evaluasi pelaksanaan pengabdian telah dilaksanakan sebagai akhir rangkaian kegiatan pengabdian ini. Pelaksanaan keseluruhan kegiatan pengabdian berlangsung dengan baik dan lancar. Mitra sangat antusias dengan kegiatan pelatihan ini. Mitra telah mendapatkan tambahan pengetahuan dan wawasan berkenaan dengan media digital pembelajaran selain media digital yang telah digunakan pada saat pembelajaran saat ini. Media pembelajaran Microsoft Teams merupakan media pembelajaran yang baru dipelajari oleh guru-guru. Namun guru-guru sudah dapat mempraktekan materi yang diberikan selama pelatihan. Tim pengusul perlu melakukan komunikasi secara intensif ke mitra supaya media pembelajaran bisa segera digunakan dalam proses pembelajaran di sekolah.

\section{Ucapan Terimakasih}

Tim Pengusul mengucapkan terima kasih pada SD Muhammadiyah 2 Denpasar yang telah berkenan menjadi mitra dalam kegiatan pengabdian ini.Kegiatan pengabdian ini didanai oleh Institut Teknologi dan Bisnis STIKOM Bali sebagai wujud pelaksanaan Tri Dharma Perguruan Tinggi. Ungkapan terima kasih yang mendalam teruntuk anggota Tim Pengabdian Alm. Ratna Kartika W. Semoga segala amal ibadahnya diterima di sisi Allah SWT. 


\section{Daftar Pustaka}

Amirullah, G. (2020). Pelatihan Pengembangan Kelas Digital Berbasis Microsoft 365 Di Sekolah Muhammadiyah Dki Jakarta. 1(3), 223-227.

Anugrahana, A. (2020). Hambatan, Solusi dan Harapan: Pembelajaran Daring Selama Masa Pandemi Covid-19 Oleh Guru Sekolah Dasar. Scholaria: Jurnal Pendidikan Dan Kebudayaan, 10(3), 282-289.

Haqien, D., \& Rahman, A. A. (2020). Pemanfaatan Zoom Meeting Untuk Proses Pembelajaran Pada Masa Pandemi Covid-19. SAP (Susunan Artikel Pendidikan), 5(1).

Ismanto, I., \& Cindarbumi, F. (2021). Analisis Efektivitas Pembelajaran Kalkulus Berbasis MS Teams pada Masa Pandemi Covid-19. MAJAMATH: Jurnal Matematika Dan Pendidikan Matematika, 4(1), 91-103.

Isti'anah, I. (2020). Pelatihan Penulisan Karya IImiah Bagi Kalangan Guru Sma Lingkup Provinsi Maluku Dan Maluku Utara Dengan Optimasi Aplikasi Microsoft Teams. Jurnal Vokasi - Politeknik Negeri Lhokseumawe, 4(2), 67. https://doi.org/10.30811/vokasi.v4i2.1989

Pradja, B. P., \& Baist, A. (2019). Analisis kualitatif penggunaan Microsoft Teams dalam pembelajaran kolaboratif daring. Seminar Nasional Matematika Dan Pendidikan Matematika (4th Senatik), 415-420. http://103.98.176.39/index.php/senatik/article/view/88

Situmorang, A. S. (2020). Microsoft Teams for Education Sebagai Media Pembelajaran. Microsoft Teams for Education Sebagai Media Pembelajaran Interaktif Meningkatkan Minat Belajar, 02(01), 30-35.

Widiyarso, T. H., \& Sutama. (2021). Efektifitas Penggunaan Microsoft Teams Dalam Pembelajaran ELearning Bagi Guru Selama Pandemi Covid-19. Jurnal Pendidikan Dan IImu Pengetahuan, 21(1), 15-21. 
